\title{
Rapid glacial retreat on the Kamchatka Peninsula during the early 21st century
}

\author{
Colleen M. Lynch, Iestyn D. Barr, Donal Mullan, and Alastair Ruffell \\ School of Natural and Built Environment, Queen's University, Belfast, BT7 1NN, UK \\ Correspondence to: Colleen M. Lynch (clynch31@qub.ac.uk)
}

Received: 8 February 2016 - Published in The Cryosphere Discuss.: 10 March 2016

Revised: 20 July 2016 - Accepted: 4 August 2016 - Published: 22 August 2016

\begin{abstract}
Monitoring glacier fluctuations provides insights into changing glacial environments and recent climate change. The availability of satellite imagery offers the opportunity to view these changes for remote and inaccessible regions. Gaining an understanding of the ongoing changes in such regions is vital if a complete picture of glacial fluctuations globally is to be established. Here, satellite imagery (Landsat 7, 8 and ASTER) is used to conduct a multi-annual remote sensing survey of glacier fluctuations on the Kamchatka Peninsula (eastern Russia) over the 2000-2014 period. Glacier margins were digitised manually and reveal that, in 2000, the peninsula was occupied by 673 glaciers, with a total glacier surface area of $775.7 \pm 27.9 \mathrm{~km}^{2}$. By 2014, the number of glaciers had increased to 738 (reflecting the fragmentation of larger glaciers), but their surface area had decreased to $592.9 \pm 20.4 \mathrm{~km}^{2}$. This represents a $\sim 24 \%$ decline in total glacier surface area between 2000 and 2014 and a notable acceleration in the rate of area loss since the late 20th century. Analysis of possible controls indicates that these glacier fluctuations were likely governed by variations in climate (particularly rising summer temperatures), though the response of individual glaciers was modulated by other (non-climatic) factors, principally glacier size, local shading and debris cover.
\end{abstract}

\section{Introduction}

Since glaciers are intrinsically linked to climate (Oerlemans et al., 1998), fluctuations in their dimensions are some of the best natural indicators of recent climate change (Lemke et al., 2007; Paul et al., 2009). In recent years, the improved quality and availability of satellite imagery has allowed fluctua- tions of glaciers in isolated and often inaccessible regions to be studied remotely (Gao and Liu, 2001; Raup et al., 2007). This can reveal key information concerning the changing local climate and provide insights into specific controls on glacier behaviour (e.g. allowing the role of climatic forcing and non-climatic modulation to be assessed) (Tennant et al., 2012; Stokes et al., 2013; Burns and Nolin, 2014). Given this utility, we use remote sensing methods to investigate recent (2000-2014) fluctuations in the surface area of glaciers on the Kamchatka Peninsula (eastern Russia) and consider possible climatic and non-climatic impacts on this behaviour. The Kamchatka Peninsula is of particular interest because investigation of its recent glacial history has been limited (cf. Khromova et al., 2014; Earl and Gardner, 2016), despite being the largest glacierised area in NE Asia (Solomina et al., 2007) and a region where glaciers, climate and active volcanoes currently interact (Barr and Solomina, 2014).

\section{Study area}

\subsection{Topography}

Located in the Russian Far East, the Kamchatka Peninsula occupies $\sim 260000 \mathrm{~km}^{2}$. It extends approximately $1250 \mathrm{~km}$ from the Koryak Highlands in the north to Cape Lopatka in the south and separates the North Pacific Ocean to the east from the Sea of Okhotsk to the west (Fig. 1). The peninsula has been shaped by both volcanic and glacial forces (Braitseva et al., 1995, 1997; Ponomareva et al., 2007, 2013; Barr and Clark, 2012a, b) and is dominated by three mountain ranges: the Sredinny (Central) Range, the Eastern Volcanic Plateau and the Vostocny (Eastern) Range (Fig. 1). Between these ranges lies the Central Kamchatka Depression, 


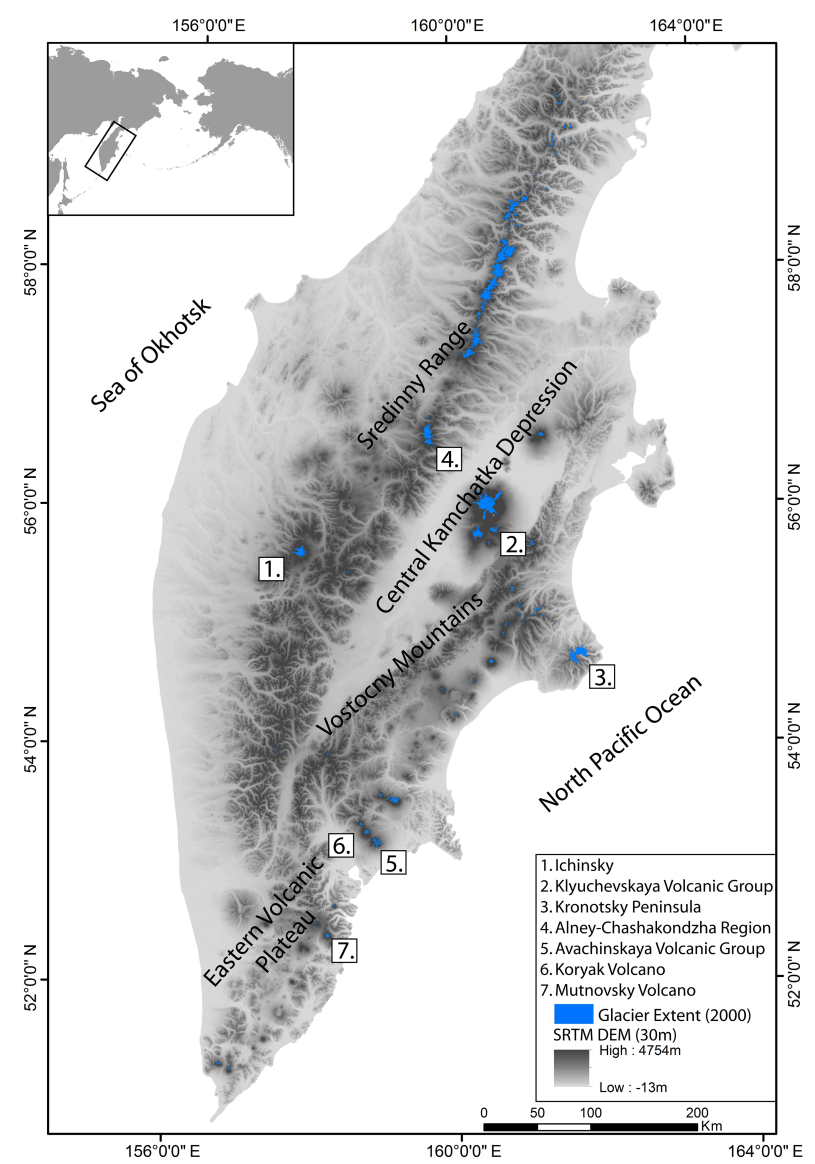

Figure 1. Map of the Kamchatka Peninsula (Russia) with glacier extent in 2000 shown in blue. Numbers refer to locations discussed in the text.

with relatively flat terrain punctuated by high volcanic peaks ( $>4000 \mathrm{~m}$ above sea level; a.s.l.). The three principal mountain ranges are orientated north-east to south-west, reflecting the position and eastward movement of the Kuril-Kamchatka subduction zone, which forms an offshore trench running almost parallel to the peninsula's eastern coastline (Bulin, 1978). This subduction zone is responsible for the 30 active and $\sim 300$ inactive volcanoes on the peninsula (Solomina et al., 2007).

\subsection{Climate}

Kamchatka lies between 50 and $61^{\circ} \mathrm{N}$, and 155 and $163^{\circ} \mathrm{E}$, and its proximity to the Pacific Ocean and Sea of Okhotsk results in a significantly milder climate than much of adjacent Siberia. Average summer temperatures range from 10 to $15^{\circ} \mathrm{C}$ (Ivanov, 2002), whilst average winter temperatures range from -8 to $-10^{\circ} \mathrm{C}$ in the south-east, and from -26 to $-28^{\circ} \mathrm{C}$ in the interior and north-west, where cold temperatures are amplified by the effects of continentality and higher altitudes. A similar gradient is visible in the precipitation regime, with average annual values of $\sim 1500-2000 \mathrm{~mm}$ in the south-east and 400-600 $\mathrm{mm}$ in the north-west. This gradient is partly a consequence of the mountain chains acting as orographic barriers, impeding and disrupting air flow from the Pacific (Barr and Clark, 2011). During winter, cold, dry air is drawn from the Siberian High over central Siberia (Barr and Solomina, 2014). However, this is tempered by the development of a low pressure system over the Sea of Okhotsk, which sustains precipitation and elevates temperatures during winter (Velichko and Spasskaya, 2002). During summer, the Pacific High, to the south-east, brings warm-moist air masses across the peninsula. Precipitation peaks during autumn, aided by the delayed onset of the East Asian monsoon (Velichko and Spasskaya, 2002).

\subsection{Glaciers}

At present, glaciers on the peninsula are found within the three principal mountain ranges and on the high volcanic peaks of the Central Kamchatka Depression (see Fig. 1). The first attempts to estimate the extent of the region's glaciers were published as part of the "Catalogue of Glaciers in the USSR, volume 20" (Vinogradov, 1968; Khromova et al., 2014). This was based on observations from topographic maps and aerial imagery captured in the early 1950s (various years), supplemented by field studies (Kotlyakov, 1980). In this survey, 405 glaciers were documented, with a total area of $\sim 874 \mathrm{~km}^{2}$ (Vinogradov, 1968). This was used as a basis for the USSR Glacier Inventory (UGI), and the dataset was subsequently incorporated within both the World Glacier Inventory (WGI) (WGMS, 1989) and Randolph Glacier Inventory (RGI) version 2 (Arendt et al., 2012). Subsequent estimates of the total number and surface area of glaciers on the peninsula tend to differ. For example, Muraviev (1999) reports 448 glaciers, with a total area of $\sim 906 \mathrm{~km}^{2}$, while Solomina et al. (2007) report 446 glaciers, with a total area of $\sim 900 \mathrm{~km}^{2}$. Most recently, Earl and Gardner (2016) conducted extensive mapping of glaciers in northern Asia using automated remote sensing techniques (i.e. NDSI), with a size threshold of $0.02 \mathrm{~km}^{2}$ and documented 984 glaciers on Kamchatka, covering a total area of $770.3 \mathrm{~km}^{2}$. These data were incorporated into the most recent version of the RGI (version 5, released in July 2015) (Arendt et al., 2015). However, it is of note that the Earl and Gardner (2016) dataset is based on a mosaic of satellite images from multiple years (2000, 2002, 2009, 2011, 2013), meaning their estimate does not reflect glacier extent at a single point in time (or during a single year).

In addition to these peninsula-wide inventories, investigations into recent glacier fluctuations in specific regions of Kamchatka have been conducted (locations identified in Fig. 1). For example, based on the analysis of satellite imagery, data from the UGI, and aerial photographs, Muraviev and Nosenko (2013) identified a $16.6 \%$ decline in glacier surface area in the northern sector of the Sredinny Range between 1950 and 2013. Muraviev (2014), using these 
Table 1. Satellite images used to generate the glacier inventory.

\begin{tabular}{llll|llll}
\hline \multicolumn{2}{c}{2000} & & & & 2014 \\
\hline Path & Row & Date & Scene ID & Path & Row & Date & Scene Id \\
\hline 98 & 21 & $22 / 09 / 2000$ & LE70980212000266EDC01 & 97 & 22 & $29 / 08 / 2014$ & LC80970222014241LGN00 \\
98 & 22 & $22 / 09 / 2000$ & LE70980222000250EDC00 & 98 & 19 & $05 / 09 / 2014$ & LC80980192014248LGN00 \\
98 & 22 & $06 / 09 / 2000$ & LE70980222000250EDC00 & 99 & 19 & $27 / 08 / 2014$ & LC80990192014239LGN00 \\
98 & 23 & $06 / 09 / 2000$ & LE70980232000250EDC00 & 99 & 20 & $27 / 08 / 2014$ & LC80990202014239LGN00 \\
99 & 18 & $28 / 08 / 2000$ & LE70990182000241EDC00 & 99 & 21 & $27 / 08 / 2014$ & LC80990212014239LGN00 \\
99 & 22 & $28 / 08 / 2000$ & LE70990222000241EDC00 & 99 & 21 & $12 / 09 / 2014$ & LC80990212014255LGN00 \\
99 & 23 & $28 / 08 / 2000$ & LE70990232000241EDC00 & 99 & 22 & $12 / 09 / 2014$ & LC80990222014255LGN00 \\
100 & 19 & $18 / 07 / 2000$ & LE71000192000200EDC00 & 99 & 23 & $27 / 08 / 2014$ & LC80990232014239LGN00 \\
100 & 20 & $19 / 08 / 2000$ & LE71000202000232EDC00 & 99 & 23 & $12 / 09 / 2014$ & LC80990232014255LGN00 \\
100 & 21 & $19 / 08 / 2000$ & LE71000212000232EDC00 & 99 & 24 & $12 / 09 / 2014$ & LC80990242014255LGN00 \\
100 & 22 & $19 / 08 / 2000$ & LE71000222000232EDC00 & 100 & 19 & $19 / 09 / 2014$ & LC81000192014262LGN00 \\
100 & 23 & $20 / 09 / 2000$ & LE71000232000264EDC00 & 100 & 20 & $19 / 09 / 2014$ & LC81000202014262LGN00 \\
100 & 24 & $20 / 09 / 2000$ & LE71000242000264EDC00 & 101 & 21 & $10 / 09 / 2014$ & LC81010212014253LGN00 \\
99 & 19 & $20 / 07 / 2000$ & AST_L1T_00307202000004626 & 101 & 22 & $10 / 09 / 2014$ & LC81010222014253LGN00 \\
& & & _20150410120043_53236 & & & & \\
\hline
\end{tabular}

same techniques, identified a $19.2 \%$ decrease in glacier surface area in the Alney-Chashakondzha region between 1950 and 2013 and a $22.9 \%$ decrease on the Kronotsky Peninsula between 1950 and 2010. On the basis of fieldwork (2007-2010) and the analysis of aerial photographs (from 1974), Manevich et al. (2015) documented fluctuations of 27 glaciers on the slopes of the Avachinsky volcanic group between 1974 and 2010 and found that, during this period, seven glaciers advanced, two retreated and eight remained largely stationary. Other, smaller-scale studies include investigations of glaciers on the slopes of Ichinsky Volcano $\left(55.690^{\circ} \mathrm{N}, 157.726^{\circ} \mathrm{E}\right)$ (see Matoba et al., 2007), Koryak Volcano $\left(53.321^{\circ} \mathrm{N}, 158.706^{\circ} \mathrm{E}\right.$ ) (see Manevich and Samoilenko, 2012), in the Klyuchevskaya volcanic group ( $\sim 56.069^{\circ} \mathrm{N}, 160.467^{\circ} \mathrm{E}$ ) (see Shiraiwa et al., 2001), and at Koryto glacier $\left(54.846^{\circ} \mathrm{N}, 161.758^{\circ} \mathrm{E}\right)$ on the Kronotsky Peninsula (see Yamaguchi et al., 1998, 2007, 2008). As a result of these investigations, some of the glaciers in the Central Kamchatka Depression have been documented as "surge-type" (Vinogradov et al., 1985). For example, Bilchenok glacier $\left(56.100^{\circ} \mathrm{N}, 160.482^{\circ} \mathrm{E}\right)$ in the Klyuchevskaya volcanic group is known to have surged $\sim 2 \mathrm{~km}$ in 1959/1960 and again in 1982/84 (Muraviev et al., 2012). In this example, surging appears unrelated to climate and is likely driven by the strengthening of seismic activity at Ushkovsky Volcano $\left(56.069^{\circ} \mathrm{N}, 160.467^{\circ} \mathrm{E}\right)$, upon which the glacier sits (Muraviev et al., 2012). Direct mass balance observations from Kamchatka's glaciers are limited, with the longest continuous record obtained for Kozelsky glacier $\left(53.245^{\circ} \mathrm{N}, 158.846^{\circ} \mathrm{E}\right)$, spanning the $1973-$ 1997 period. Other mass balance measurements, from Koryto, Mutnovsky SW $\left(52.448^{\circ} \mathrm{N}, 158.181^{\circ} \mathrm{E}\right)$, Mutnovsky $\mathrm{NE}\left(52.460^{\circ} \mathrm{N}, 158.220^{\circ} \mathrm{E}\right)$, and Kropotkina $\left(54.321^{\circ} \mathrm{N}\right.$, $\left.160.034^{\circ} \mathrm{E}\right)$ glaciers, are far shorter and often discontinuous (see Barr and Solomina, 2014).

\section{Methods}

\subsection{Data sources}

Changes in glacier extent on the Kamchatka Peninsula between 2000 and 2014 were determined through visual analysis of multi-spectral Landsat 7 Enhanced Thematic Mapper Plus (ETM+), Landsat 8 Operational Land Imager (OLI), and Terra Advanced Spaceborne Thermal Emission and Reflection Radiometer (ASTER) satellite images (see Table 1). Orthorectified scenes were obtained from the USGS Earth Explorer website (http://earthexplorer.usgs.gov/) and projected using WGS 1984 Universal Transverse Mercator (UTM) zone $57 \mathrm{~N}$, then filtered to find those with minimal cloud cover and snow cover. To achieve this, images were restricted to those captured during the ablation season (for Kamchatka this occurs from late July to early September). Satellite images captured prior to 2000 (e.g. Landsat MSS and CORONA) were obtained and analysed; however images captured during the ablation season, with minimal snow cover and cloud cover were limited, and full coverage of the peninsula's glaciers was lacking. As a result, the present study only focuses on 2000 and 2014 (i.e. those years with full satellite coverage of the region's glaciers). In total, 14 Landsat $7(\mathrm{ETM}+)$ scenes and 1 ASTER image were used for 2000, with 14 Landsat 8 (OLI) scenes used for 2014 (see Table 1). The Landsat scenes have a spatial resolution of $30 \mathrm{~m}$ for all bands except panchromatic band $8(15 \mathrm{~m})$ and Thermal Infrared Sensor (TIRS) band $6(60 \mathrm{~m})$, whilst the ASTER image (bands 1-3) has a spatial resolution of $15 \mathrm{~m}$. 
To analyse glacier topography, SRTM 1 Arc-Second Global elevation data were obtained from the USGS Earth Explorer website. This reflects the surface topography of the glaciers in February 2000, with a horizontal resolution of $\sim 30 \mathrm{~m}$ and with vertical errors $<16 \mathrm{~m}$ (at the $90 \%$ confidence level) (Farr et al., 2007).

\subsection{Delineation of glacier margins}

As highlighted by Paul et al. (2013), the identification and mapping of glaciers from satellite images can be conducted using semi-automated techniques (e.g. Paul and Andreassen, 2009; Kamp and Pan, 2015; Smith et al., 2015; Earl and Gardner, 2016) or through manual digitising (e.g. DeBeer and Sharp, 2007; Stokes et al., 2013). In the present study, in order to establish the best method for mapping glaciers on Kamchatka, both semi-automated techniques and manual digitisation were trialled. The semi-automated techniques (specifically a RED/SWIR ratio and Normalised Difference Snow Index (NDSI)) produced rapid outputs and were easily applied across large regions but had difficulty differentiating ice from the surrounding environment (Fig. 2). The RED/SWIR band ratio had particular problems in distinguishing shaded areas and dirty ice, while the NDSI sometimes failed to distinguish ice from clouds and water bodies. Due to these difficulties, combined with the extensive manual editing and post-processing required to produce precise glacier margins, the semi-automated techniques were rejected in favour of manual mapping. Although timeconsuming and sometimes subjective (Bhambri et al., 2011; Paul et al., 2013; Pfeffer et al., 2014), manual mapping remains the best method to extract detailed information on glacier dimensions (Kääb, 2005) whilst additionally allowing snow patches and areas covered by shadow to be identified (see Fig. 2).

To help differentiate glaciers from their surroundings and aid in the visual detection of glacier margins, both true- and false-colour composites of the satellite images were generated (Malinverni et al., 2008), with the high-resolution band $8(15 \mathrm{~m})$ used to sharpen the image. The true-colour composites were used for the identification of glaciers, while the false-colour composites helped differentiate ice and cloud, due to the strong absorption of ice in the SWIR band when compared to clouds (Nuimura et al., 2015). Glaciers were mapped in ArcGIS 10.2.2 (by a single operator) as polygon shapefiles, and features $<0.02 \mathrm{~km}^{2}$ in 2000 were excluded from the analysis on the grounds that they are likely to be snow or ice patches, rather than glaciers (Paul and Andreassen, 2009; Paul et al., 2009; Bajracharya and Shresta, 2011; Frey et al., 2012; Racoviteanu et al., 2015). To help verify that each of the digitised polygons was a glacier rather than a transient snow patch, scenes from intervening years, including 2015, were also obtained and analysed (Paul et al., 2009). However, the glacier inventory produced here does not contain detailed information about glacier dimensions for

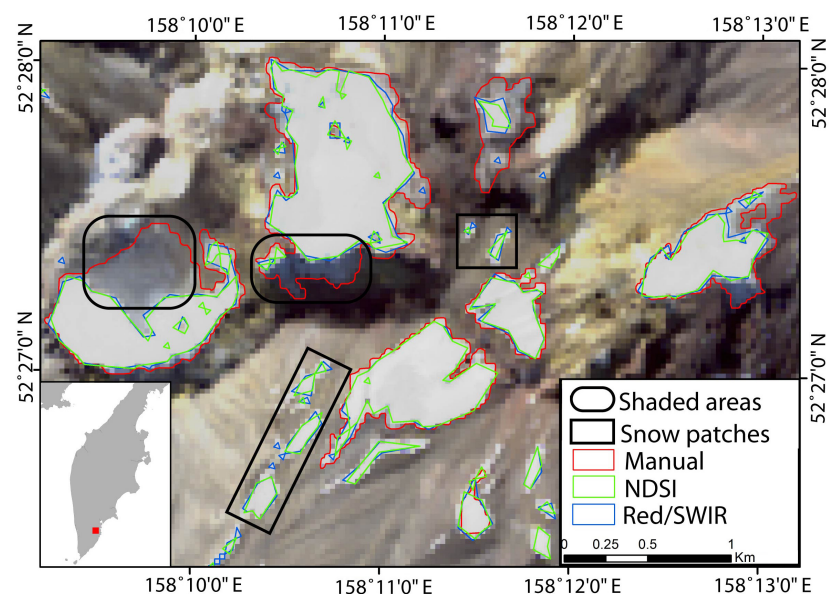

Figure 2. Comparison of glacier margins (on the slopes of Mutnovsky Volcano) delineated by two semi-automated techniques and manual mapping (Landsat 2014 background image). This figure illustrates how manual mapping can help identify snow patches and shaded areas of glacier ice, thereby allowing the former to be discounted from, and the latter included in, the glacier inventory.

these intervening years since complete peninsula-wide imagery without extensive snow cover or cloud cover was unavailable for these periods, meaning that not all glaciers were mapped. For each of the glaciers mapped in 2000 and 2014, two-dimensional surface area was measured directly from the shapefiles, and area differences between 2000 and 2014 were calculated. Where glaciers fragmented into several distinct ice masses over this period, the net change in area was calculated based on the sum of the total area of each of the glacier "fragments" (following DeBeer and Sharp, 2007). For each glacier identified in the inventory in 2000, maximum, minimum and median altitude as well as mean surface slope were calculated from the SRTM digital elevation model (DEM), and generalised glacier aspect was estimated from a line connecting the glacier's maximum and minimum altitudes. The mean annual receipt of solar radiation at the surface of each glacier was calculated using the "Solar Radiation" tool in ArcGIS (algorithms developed by Fu and Rich, 2002), and glacier length was estimated along inferred flow lines.

\subsection{Error estimation}

Potential sources of error in this study arise through the digitisation process and with difficulties in correctly identifying areas of glacial ice. The accuracy of digitisation depends partly on the spatial resolution of the satellite imagery, snow conditions and the contrast between glacier ice and the surrounding environment (DeBeer and Sharp, 2007; Stokes et al., 2013). In Kamchatka, it is notable that the maritime conditions create particular difficulty with locating cloudfree imagery, and persistent snow cover often hinders the clear identification of glacier margins (Paul and Andreassen, 2009). Where glacier margins were partially obscured by 
shadow, debris or cloud, careful analysis using multiple trueand false-colour composite band images, as well as thermal imagery, was undertaken. Error was calculated following the method described in Bajracharya et al. (2014):

$\mathrm{RMSE}=\sqrt{\frac{\sum_{i=1}^{n}\left(a_{i}-\hat{a}_{i}\right)^{2}}{n}}$,

where $a_{i}$ denotes glacier area and $\hat{a}_{i}$ is the glacier area calculated on the pixel base (i.e. the total number of pixels within a polygon, multiplied by the highest image resolution $(15 \mathrm{~m})$ used for mapping), and $n$ is the number of polygons digitised. Error was found to be $\sim 3.6 \%$ in 2000 and $\sim 3.4 \%$ in 2014 . These values are comparable to those reported in other studies (Bolch et al., 2010; Bhambri et al., 2013; Bajracharya et al., 2014).

\subsection{Climate data}

NCEP/NCAR reanalysis data (see Kalnay et al., 1996) were used to analyse recent fluctuations in climate across Kamchatka. The NCEP reanalysis data integrate available land surface data from climate stations with the recovery of data from radiosondes, aircraft, ships and satellites to assimilate a quality-controlled gridded $\left(1.88^{\circ}\right.$ latitude $\times 1.88^{\circ}$ longitude) record of surface climate variables for the period 1948present (Kalnay et al., 1996). The precipitation data reflect surface conditions, and temperature data reflect conditions at a height of $2 \mathrm{~m}$ a.s.l. Reanalysis data were used in preference to analysing individual weather stations, since the latter are often situated in coastal locations, distant from Kamchatka's glaciers. Additionally, many of the available station records include periods of missing data.

\section{Results}

\subsection{Glacier inventory in 2000}

In total, 673 glaciers, with a combined surface area of $775.7 \pm 27.9 \mathrm{~km}^{2}$, were identified and mapped on the peninsula in 2000 (see Fig. 1). Summary statistics for these glaciers are presented in Table 2, revealing a mean surface area of $1.15 \mathrm{~km}^{2}$ (ranging from 0.02 to $48.82 \mathrm{~km}^{2}$ ), with $\sim 77 \%<1 \mathrm{~km}^{2}$, and less than $4 \%>5 \mathrm{~km}^{2}$, though the latter represent just over one-third of the total glacier area. Glaciers range in length from $0.17 \mathrm{~km}$ to $20.96 \mathrm{~km}$, while ranging in altitude from 273 to $4407 \mathrm{~m}$ a.s.l., with a mean altitudinal range of $465 \mathrm{~m}$, and a mean surface slope of $17^{\circ}$. The mean annual receipt of solar radiation at the surface of each glacier ranges from 489.8 to $1012.4\left(\mathrm{kWh} \mathrm{m}^{-2}\right)$. Across the peninsula, 52 glaciers have tongues covered with debris (rock and ash), the majority of which exist on volcanic slopes in the Central Kamchatka Depression (see Yamaguchi et al., 2007).
Table 2. Statistics for glaciers on the Kamchatka Peninsula in 2000 (topographic attributes are derived from the SRTM 30 m DEM).

\begin{tabular}{lrrr}
\hline & Min & Mean & Max \\
\hline Area $\left(\mathrm{km}^{2}\right)$ & 0.02 & 1.15 & 48.82 \\
Minimum altitude (m a.s.l) & 273 & 1277 & 2920 \\
Median altitude (m a.s.l.) & 544 & 1506 & 3539 \\
Maximum altitude (m a.s.l.) & 577 & 1742 & 4407 \\
Altitudinal range (m) & 17 & 465 & 3104 \\
Maximum flow-line length $(\mathrm{km})$ & 0.17 & 1.74 & 20.96 \\
Mean surface slope ( $\left.{ }^{\circ}\right)$ & 5.7 & 17.0 & 35.5 \\
Mean annual solar radiation $\left(\mathrm{kWh} \mathrm{m}^{-2}\right)$ & 489.8 & 817.1 & 1012.4 \\
\hline
\end{tabular}

\subsection{Changes in glacier number and extent between 2000 and 2014}

In 2014, 738 glaciers, covering an area of $592.9 \pm 20.4 \mathrm{~km}^{2}$, were identified and mapped on the peninsula. This represents an additional 65 glaciers, but an overall area loss of $182.9 \pm 6.6 \mathrm{~km}^{2}(\sim 24 \%)$, relative to 2000 . The increase in glacier number occurred despite the loss of 46 glaciers during this period (these glaciers were all $<0.5 \mathrm{~km}^{2}$ in 2000 and either completely disappeared or fell below the size threshold of $0.02 \mathrm{~km}^{2}$, by 2014) (see Fig. 3) and primarily reflects the fragmentation of larger glaciers. Of the peninsula's 673 glaciers identified in 2000, $654(\sim 97 \%)$ experienced a reduction in surface area by 2014 , and this decline is seen across the peninsula (Fig. 4). Of the 17 glaciers that increased in area during this period, the majority experienced minor growth. One glacier increased by $\sim 140 \%$ (see Fig. $4 \mathrm{~b}$ ) but was very close to the size threshold of $0.02 \mathrm{~km}^{2}$ in 2000 , and the area gain over the period of observation only equates to $0.03 \mathrm{~km}^{2}$. In addition to areal decline, signs of stationary thinning (downwasting) are apparent in many areas, reflected by the exposure of many rock outcrops and the fragmentation of glaciers (see Fig. 5). The exposure of bedrock in this way further accelerates glacier wastage as local albedo is reduced (Paul et al., 2007).

\subsection{Climate}

When analysed across the peninsula, the NCEP data appear to indicate a reduction in precipitation between the 1970s and 1990s but a precipitation increase thereafter (see Fig. 6a). This recent increase in precipitation is particularly notable during autumn (Fig. 6a), though more importantly for glacier mass balance, winter precipitation also increases during this period, likely contributing directly to increased snow accumulation. The temperature data (Fig. 6b) appear to show a warming trend from the 1950s to the late 1990s, which has continued (with some fluctuations) to the present day. Most significantly, there has been a sharp increase in average summer temperatures (June, July and August) since the early $21 \mathrm{st}$ century (see Fig. 6b). 


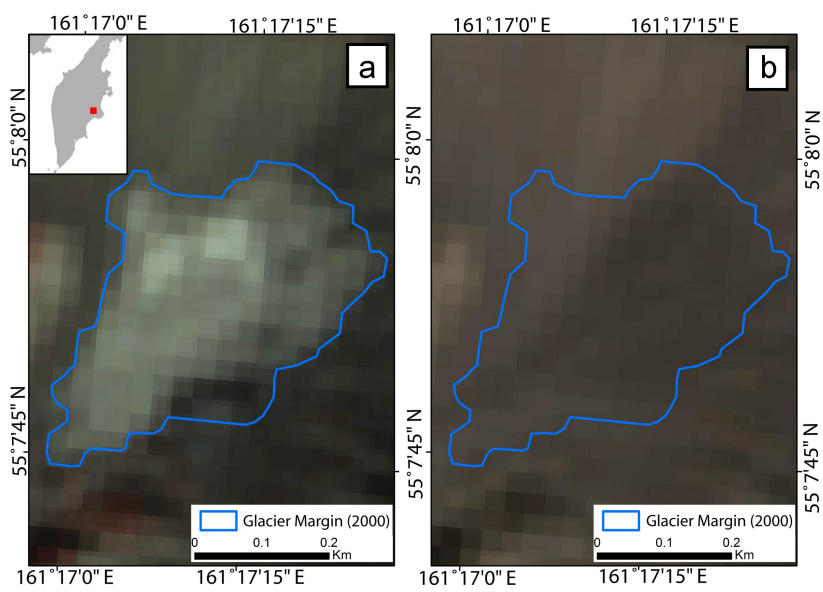

Figure 3. Example of a small glacier in the Vostocny Mountains that disappeared between 2000 (a) and 2014 (b). In both (a) and (b), the background is a Landsat image.

\subsection{Glacier attributes and glacier area change}

Glacier size (area, perimeter, length and altitudinal range), altitude (maximum, median and minimum), surface slope and aspect (based on the glaciers mapped in 2000) were compared to absolute and relative changes in glacier surface area across the peninsula. These comparisons reveal a strong negative and statistically significant $(p<0.001)$ correlation between the 2000 to 2014 change in glacier surface area (in $\mathrm{km}^{2}$ ) and glacier area $(r=-0.75)$, length $(r=-0.65)$ and altitudinal range $(r=-0.48)$ in 2000 (Fig. 7a-c). When change in area is expressed as a percentage of the original glacier size (rather than total area), these correlations become positive $(r=0.24,0.34$ and 0.34 for surface area, length and altitudinal range, respectively) and are weakened (though they remain statistically significant) (Fig. $7 \mathrm{~d}-\mathrm{f}$ ). There is also a negative and statistically significant correlation between glacier surface area change (in $\mathrm{km}^{2}$ ) and the maximum $(r=-0.37)$ and median $(r=-0.25)$ glacier altitude. Again, when area change is expressed as a percentage, these correlations become positive $(r=0.23$ and 0.17 for maximum and median, respectively) and are weakened (though they remain statistically significant). When glacier minimum altitude or surface slope are considered, there is no statistically significant relationship with glacier area loss (when expressed as total area, or as percentage change). Glaciers are predominantly found with an aspect bias towards northerly and western directions (54.98\%), and glacier aspect shows a weak $(r=0.15)$ but statistically significant relationship with changes in glacier surface area, though only when expressed in $\mathrm{km}^{2}$, rather than as a percentage. Similarly, analysis of insolation patterns reveals a weak but statistically significant correlation $(r=0.18)$ with change in glacier surface area, but only when expressed in $\mathrm{km}^{2}$, rather than as a percentage.
Based on mapping in 2000, $~ 8 \%(n=52)$ of the peninsula's glaciers are classed as debris-covered. When the glacier population is split into "debris-covered" and "nondebris-covered" samples in this way, the former lose on average $\sim 11 \%\left(0.62 \mathrm{~km}^{2}\right)$ of their surface area between 2000 and 2014, while the latter lose $\sim 44 \%\left(0.24 \mathrm{~km}^{2}\right)$. Thus, over the 2000-2014 period, debris-covered glaciers lose less surface area than non-debris-covered examples, though this relationship is only statistically significant when values are expressed as a percentage, rather than in $\mathrm{km}^{2}$.

\section{Discussion}

\subsection{Comparison with other inventories}

Based on the data presented in the Catalogue of Glaciers in the USSR (see Sect. 2.3) and the findings of the present study, there was $\mathrm{a} \sim 11.2 \%$ decline in glacier surface area on the Kamchatka Peninsula between the 1950s (exact date unspecified) and 2000 and a further $\sim 23.6 \%$ loss between 2000 and 2014. Assuming linear trends, this indicates an area-loss rate of $\sim 0.24-0.29 \% \mathrm{a}^{-1}$ between 1950 and 2000 and a notable acceleration to $\sim 1.76 \% \mathrm{a}^{-1}$ since 2000 . The reduction in glacier area during the late 20th century coincides with negative trends in glacier mass balance on the peninsula (see Barr and Solomina, 2014). Unfortunately, since 2000, mass balance data have not been collected for Kamchatka's glaciers, and it is not possible to assess whether accelerated mass loss over the early 21 st century has coincided with the accelerated glacier shrinkage identified here.

Similar rates of retreat have been found for glaciers in other Asian mountain ranges. For example, in the Altai Mountains, Narozhniy and Zemtsov (2011) document a $10.2 \%$ decrease in glacier area between 1956 and 2008, while Kamp and Pan (2015) document a $13 \%$ decrease between 1998/2001 and 2010/2011. In the Tien Shan, Farinotti et al. (2015) document an $18 \pm 6 \%$ decrease in glacier surface area between 1961 and 2012. In the Kodar Mountains, Stokes et al. (2013) document a $44 \%$ decrease in the area of exposed glacial ice between 1963 and 2010, with a $40 \%$ loss since 1995, and in the Caucasus Mountains, Tielidze (2016) documents a $36.9 \pm 2.2 \%$ decline in glacier surface area between 1960 and 2014, though regional differences are noted.

In terms of glacier surface area, it is notable that our estimate from $2014\left(592.9 \pm 20.4 \mathrm{~km}^{2}\right)$ differs significantly from Earl and Gardner's (2016) estimate $\left(770.3 \mathrm{~km}^{2}\right)$. This we attribute to their semi-automated approach to mapping (i.e. NDSI), which can lead to an overestimation of glacier area as a result of snow patches being erroneously classified as glaciers (Man et al., 2014) (see Fig. 8), combined with the fact that their inventory was generated from a composite of satellite images, meaning their mapping does not reflect glacier extent during a single specified year (as noted in Sect. 2.3). 

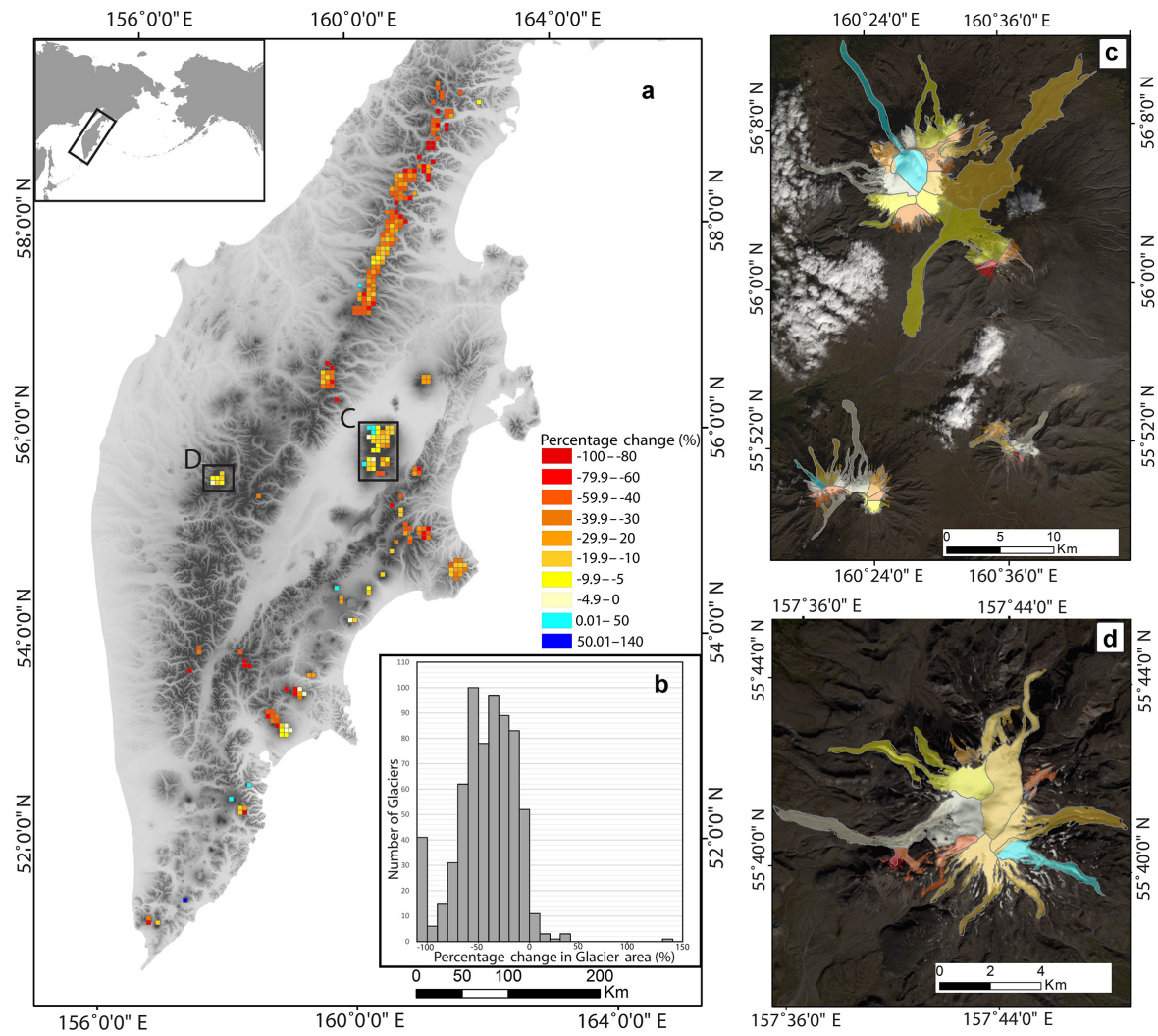

Figure 4. Percentage change in glacier surface area across the Kamchatka Peninsula between 2000 and 2014. (a) Mean values shown for $5 \times 5 \mathrm{~km}$ grid cells. (b) Values for individual glaciers shown as a frequency distribution. (c) Values for individual glaciers in the Klyuchevskaya volcanic group. (d) Values for individual glaciers on the slopes of Ichinsky Volcano. In both (c) and (d), the colour scheme from (a) is used.

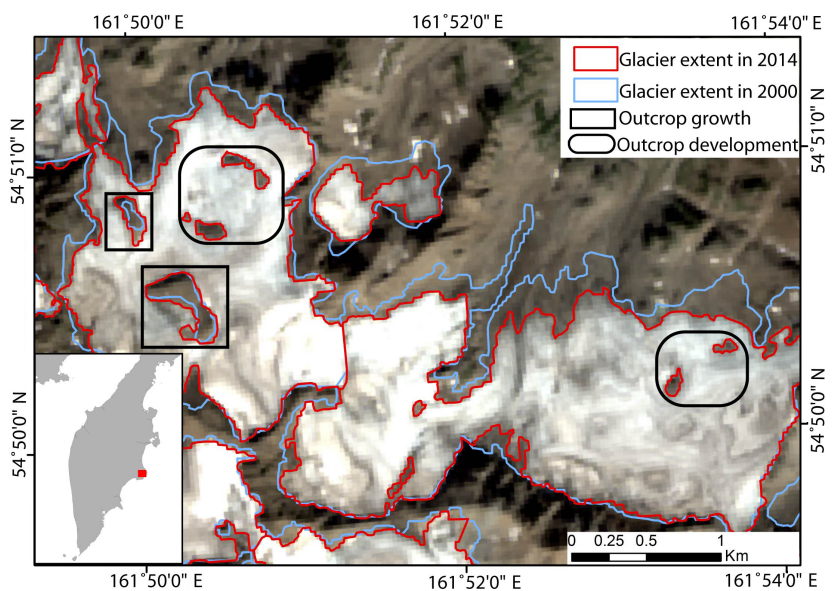

Figure 5. Examples of glaciers on the Kronotsky Peninsula mapped in 2000 and 2014 (Landsat 2014 background image), revealing stationary thinning and a notable decline in glacier surface area.

\subsection{Potential climatic controls on glacier fluctuations}

In the small number of studies to consider the issue (noted in Sect. 2.3), the retreat of Kamchatka's glaciers over re- cent decades has typically been attributed to variations in climate. For example, Yamaguchi et al. (2008) consider the retreat of Koryto glacier between 1711 and 2000 to be a result of decreased precipitation over this period. Similarly, in the northern part of the Sredinny Range, Muraviev and Nosenko (2013) note that from 1950 to 2002, average summer temperatures increased, while solid precipitation (snowfall) decreased, suggesting that this caused the retreat of the region's glaciers.

Based on climatic trends identified from the NCEP data, it might be argued that the loss of glacier surface area across Kamchatka between the 1950s and 2000 reflects the combined influence of rising temperatures and declining precipitation. However, since 2000, despite an increase in precipitation, glacier area loss has continued and appears to have accelerated. This might reflect a delayed response to earlier drier conditions, but is also likely driven by a notable increase in temperatures since the mid-1990s. In particular, the pronounced rise in summer temperature (see Fig. 6c) is likely to have increased the intensity of melt, whilst rising autumn temperatures (Fig. 6b) may have lengthened the ablation season (simultaneously shortening the accumulation season). Therefore, it would appear that temperature has been the primary control on early 21 st century glacier fluctuations 

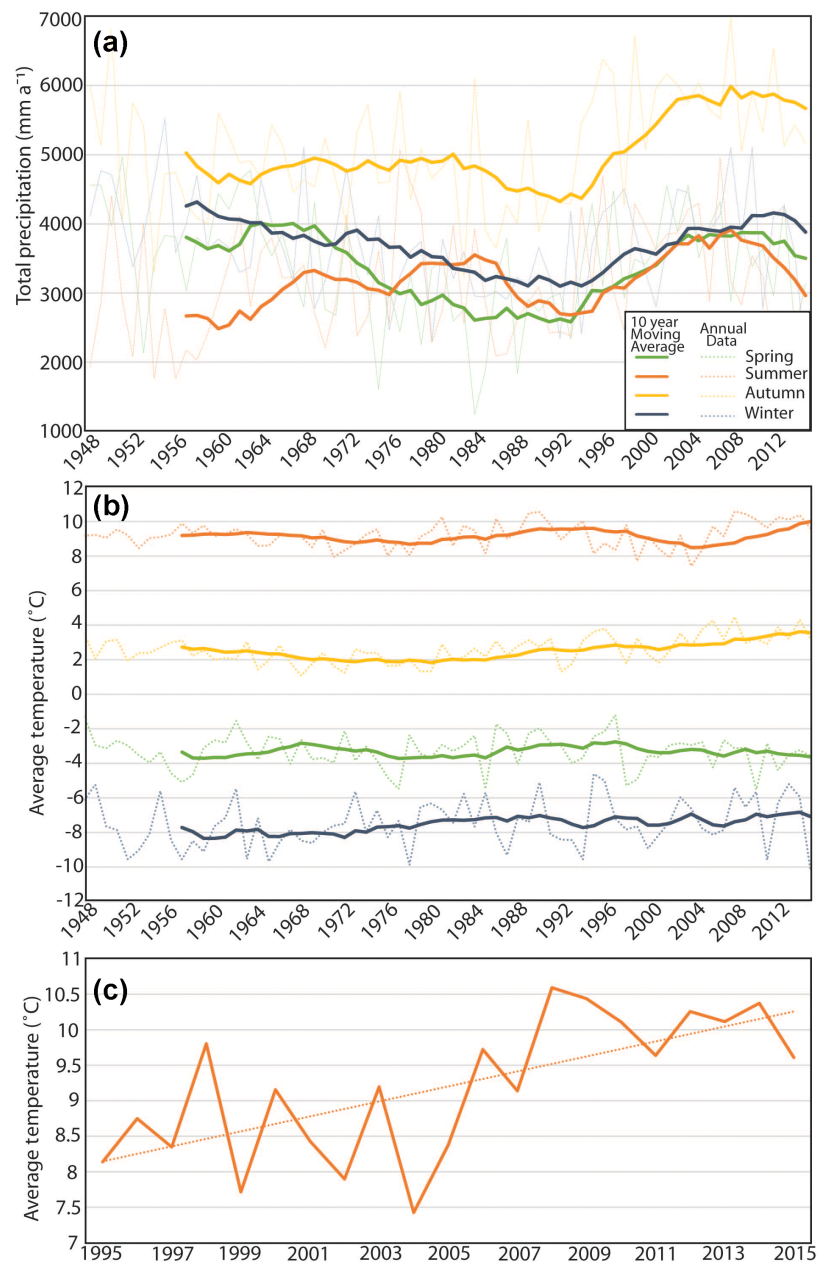

Figure 6. Climatic variation on the Kamchatka Peninsula between 1948 and 2015, derived from NCEP/NCAR daily reanalysis figures averaged across the whole peninsula (see Kalnay at al., 1996). (a) Seasonal precipitation record. (b) Average seasonal temperature. (c) Summer temperature record from 1995 to 2015.

in Kamchatka, with rising temperatures driving a notable decline in glacier surface area, despite a corresponding rise in precipitation (even during winter).

\subsection{Potential non-climatic modulation of glacier fluctuations}

Despite evidence for climatic control over glacier fluctuations in Kamchatka (outlined in Sect. 5.2), the individual response of these glaciers is likely to have been modulated by other local non-climatic factors (Evans, 2006; Tennant et al., 2012; Stokes et al., 2013). These factors potentially include glacier size (area, perimeter length and altitudinal range), altitude surface slope, and aspect, as well as volcanic controls and debris cover (Huss, 2012; Fischer et al., 2015).

\subsubsection{Glacier size}

Comparisons between glacier size and surface area fluctuations suggest that smaller glaciers, though losing the least surface area, actually lost a greater proportion of their total area. Similar trends, with small glaciers showing a propensity to shrink rapidly, have been found in numerous regions globally (see Ramírez et al., 2001; Granshaw and Fountain, 2006; Tennant et al., 2012; Stokes et al., 2013; Racoviteanu et al., 2015). This is considered a result of the greater volume-to-area and perimeter-to-area ratios of smaller glaciers - meaning they respond rapidly to a given ablation rate (Granshaw and Fountain, 2006; Tennant et al., 2012). This rapid decline in the area of smaller glaciers on the Kamchatka Peninsula could result in the loss of many over coming decades, as $\sim 75 \%$ of the glaciers mapped in 2014 have an area $<0.5 \mathrm{~km}^{2}$, of which $\sim 87 \%$ have a maximum altitude $<2000$ ma.s.l., likely making them particularly sensitive to future warming. This supports the view of Ananicheva et al. (2010), who suggest that, by 2100 , only the largest glaciers on the highest volcanic peaks will remain.

\subsubsection{Glacier altitude}

Comparisons between glacier median and maximum altitude and surface area fluctuations would appear to suggest that these factors exert some control on area change. However, the lack of any statistically significant relationship between area loss and minimum altitude might indicate that, rather than exerting a direct control on glacier area, glaciers with high maximum and median altitudes are typically the largest on the peninsula (i.e. there are positive and statistically significant relationships between glacier area and both maximum $(r=0.37)$ and median $(r=0.25)$ altitude), and that size exerts the primary control on glacier behaviour in this relationship. Similar trends, highlighting the relationship between glacier area and elevation, have been observed in other regions globally, for example in the Kanchenjunga-Sikkim region of the Himalayas (Racoviteanu et al., 2015) and in Cordillera Blanca, Peru (Racoviteanu et al., 2008).

\subsubsection{Glacier aspect}

The aspect bias exhibited by Kamchatkan glaciers, combined with the statistically significant relationship between area loss and total insolation indicates that glaciers exposed to most solar radiation typically show a greater reduction in their overall surface area (see Evans, 2006). However, though statistically significant, the relationship between glacier aspect and changes in glacier surface area is comparatively weak, suggesting that local variations in insolation (e.g. related to topographic shading) are likely important in protecting glaciers from recession (see Paul and Haeberli, 2008; Stokes et al., 2013) 

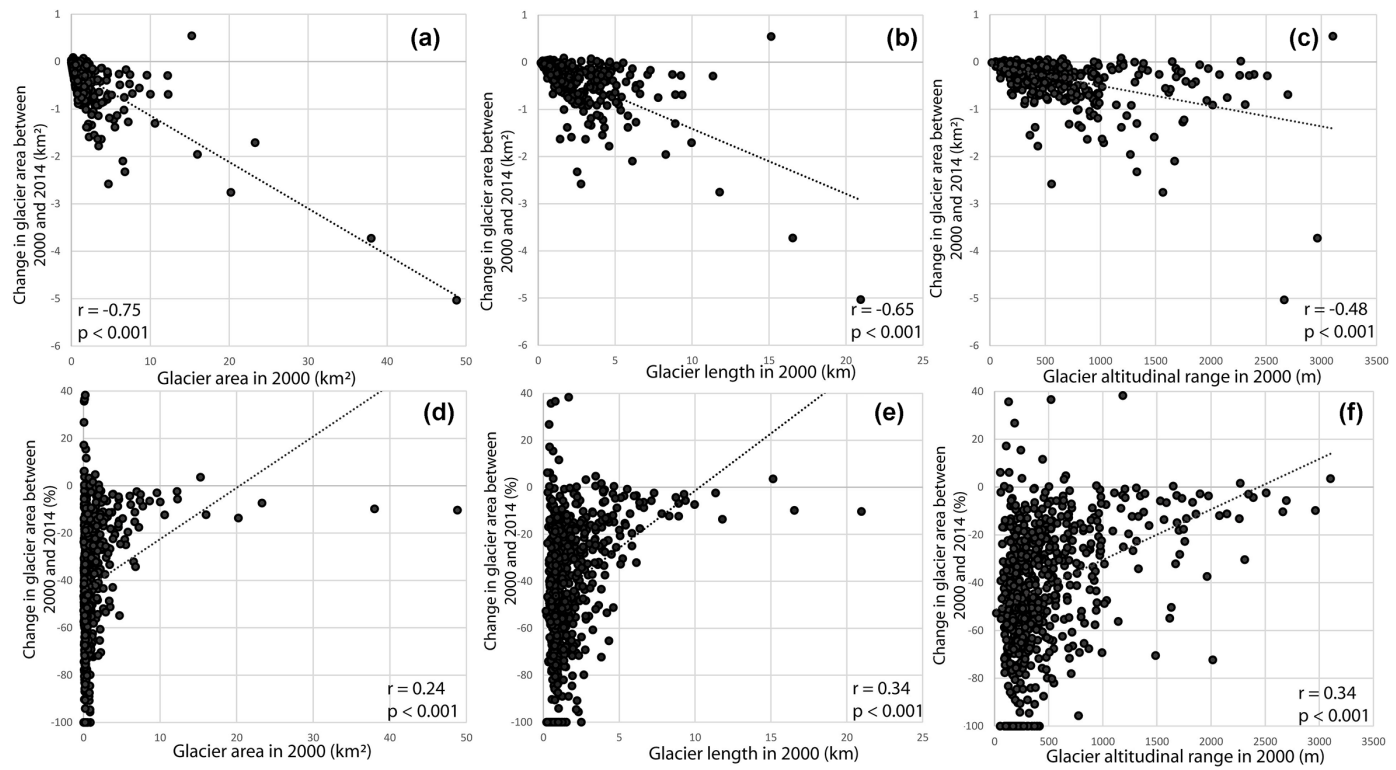

Figure 7. Relationships between glacier area changes from 2000 to 2014 (in $\mathrm{km}^{2}$ ) and glacier (a) surface area, (b) length and (c) altitudinal range. These same relationships, but with percentage area loss are plotted in (d), (e) and (f).
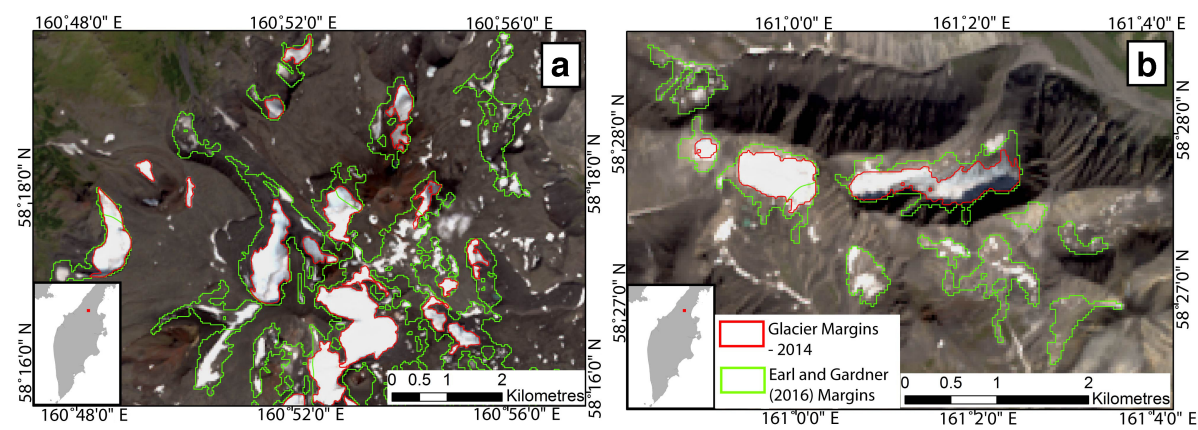

Figure 8. Comparisons, from across Kamchatka, between our mapping (based on Landsat 8 imagery captured in 2014) and the mapping of Earl and Gardner (2016).

\subsubsection{Volcanic controls and debris cover}

Across the peninsula, 165 glaciers are located within a $50 \mathrm{~km}$ radius of an active volcano, with 292 glaciers within a $100 \mathrm{~km}$ radius. During the period of observation (i.e. 20002014), > 40 individual volcanic eruptions were documented on the peninsula (VONA/KVERT, 2016). Although there is evidence that some glaciers were covered by tephra as a result of these eruptions, there is no evidence to suggest that this had a discernible influence on glacier fluctuations during the period of observation. This likely reflects the longer response time of glaciers to tephra deposition, since a number of Kamchatka's glaciers are known to have responded to volcanic ash cover over longer time periods (see Barr and Solomina, 2014). It is also apparent, from the present study, that debris-covered glaciers on the peninsula are typically less responsive to external forcing, since they lose less surface area (both in absolute and, particu- larly, relative terms) than non-debris-covered examples. Similar patterns have been observed for debris-covered glaciers elsewhere. For example, in the Kanchenjunga-Sikkim area, largely debris-free glaciers showed a $34 \%$ decline in surface area between 1962 and 2006, whilst debris-covered glaciers experienced a $22 \%$ decline over this period (Racoviteanu et al., 2015). This tendency for debris-covered glaciers to retreat comparatively little might reflect the insulating influence of accumulated surface debris (Vinogradov et al., 1985) or might indicate that the terminus positions of such glaciers are inclined to stabilise even when the glaciers are experiencing mass loss. Such a trend was identified in the central Tien Shan, where Pieczonka and Bolch (2015) found that glaciers (many of which are debris-covered) experienced comparatively little area change (below the global average) between 1975 and 1999, despite mass loss similar to the global average over this period. 
In addition to the influence exerted by surface debris, some of Kamchatka's glaciers are known to be of "surge-type", with surface indicators of past surge activity (e.g. looped moraines and heavy crevassing) (see Copland et al., 2003) and with documented surges during the 20th century (as noted in Sect. 2.3) (Vinogradov et al., 1985; Yamaguchi et al., 2007). However, there was no evidence of surging during the period of observation. This might reflect the comparatively short time period considered or may be a reflection of volcanically controlled surging (see Sect. 2.3) (Muraviev et al., 2012), which therefore lacks periodicity.

\section{Conclusions}

In this paper, manual digitisation from satellite imagery is used to map the surface area of all glaciers on the Kamchatka Peninsula in 2000 and 2014. This is the first study to consider peninsula-wide patterns in glacier behaviour over the early 21 st century, and variations in glacier extent are put into context through comparison with published glacier extent estimates from the 1950s (Kotlyakov, 1980). The main study findings can be summarised as follows:

1. In total, 673 glaciers, with a combined surface area of $775.7 \pm 27.9 \mathrm{~km}^{2}$, were identified and mapped on the peninsula in 2000. By 2014, the total number of glaciers had increased to 738 but their surface area had reduced to $592.9 \pm 20.4 \mathrm{~km}^{2}$. This suggests an acceleration in the rate of area loss since 2000 (from $\sim 0.24-0.29 \% \mathrm{a}^{-1}$ between the $1950 \mathrm{~s}$ and 2000 , to $\sim 1.76 \% \mathrm{a}^{-1}$, between 2000 and 2014). The increase in glacier number, despite the disappearance of 46 , is considered to reflect the fragmentation of larger glaciers during this period.

2. Based on the analysis of NCEP/NCAR reanalysis climate data, it appears that the reduction in glacier surface area on the peninsula between the 1950s and 2000 likely reflects the combined influence of rising temperatures and declining precipitation. However, accelerated area loss since 2000 , despite increased precipitation, is likely a response to a notable increase in temperatures across the peninsula since the 1990s. Specifically, the rise in summer temperatures is likely to have enhanced the intensity of melt, whilst rising autumn temperatures may have lengthened the ablation season, simultaneously shortening the accumulation season.

3. Despite the overall climatic control there is evidence that the behaviour of individual glaciers on the peninsula is modulated by local non-climatic factors. Specifically, smaller glaciers, though losing the least absolute surface area, lost a greater proportion of their total area. This propensity to shrink rapidly is considered to reflect the greater volume-to-area and perimeterto-area ratios of smaller glaciers, meaning that they have a heightened sensitivity to changing climate (see Granshaw and Fountain, 2006). Though glacier altitude shows some relation with area change, this probably reflects the positive relationship between glacier altitude and size (rather than an altitudinal control on glacier behaviour). Insolation patterns show a weak but statistically significant relationship with changing glacier surface area, indicating that glaciers exposed to most solar radiation experienced a greater reduction in their overall surface area. However, though statistically significant, the relationship between glacier aspect and changes in glacier surface area is comparatively weak, suggesting that local variations in insolation (e.g. related to topographic shading) are important in regulating fluctuations of Kamchatka's glaciers.

4. If the rapid decline in the surface area of smaller glaciers on the Kamchatka Peninsula continues over the 21st century, many will be lost by 2100 (Ananicheva et al., 2010), since $\sim 75 \%$ of the region's glaciers identified in 2014 have an area $<0.5 \mathrm{~km}^{2}$, of which $\sim 87 \%$ have a maximum altitude $<2000 \mathrm{~m}$ a.s.l., likely making them particularly sensitive to future warming.

\section{Data availability}

The data described in this article are the foundation of an ongoing doctoral thesis (to be completed in 2018). As a result, we are reluctant to provide access to the underlying research data at this stage. However, we are happy to release the data after this date.

Acknowledgements. We would like to acknowledge the financial support provided by the Engineering and Physical Sciences Research Council (EPSRC) (1492911).

Edited by: T. Bolch

Reviewed by: two anonymous referees

\section{References}

Ananicheva, M. D., Krenke, A. N., and Barry, R. G.: The Northeast Asia mountain glaciers in the near future by AOGCM scenarios, The Cryosphere, 4, 435-445, doi:10.5194/tc-4-435-2010, 2010.

Arendt, A., Bolch, T., Cogley, J. G., Gardner, A., Hagen, J.-O., Hock, R., Kaser, G., Pfeffer, W. T., Moholdt, G., Paul, F., Radić, V., Andreassen, L., Bajracharya, S., Beedle, M., Berthier, E., Bhambri, R., Bliss, A., Brown, I., Burgess, E., Burgess, D., Cawkwell, F., Chinn, T., Copland, L., Davies, B., De Angelis, H., Dolgova, E., Filbert, K., Forester, R., Fountain, A., Frey, H., Giffen, B., Glasser, N., Gurney, S., Hagg, W., Hall, D., Haritashya, U. K., Hartmann, G., Helm, C., Herreid, S., Howat, I., Kapustin, G., Khromova, T., Kienholz, C., Koenig, M., Kohler, J., Kriegel, D., Kutuzov, S., Lavrentiev, I., LeBris, R., Lund, J., 
Manley, W., Mayer, C., Miles, E., Li, X., Menounos, B., Mercer, A., Moelg, N., Mool, P., Nosenko, G., Negrete, A., Nuth, C., Pettersson, R., Racoviteanu, A., Ranzi, R., Rastner, P., Rau, F., Raup, B. H., Rich, J., Rott, H., Schneider, C., Seliverstov, Y., Sharp, M., Sigurðsson, O., Stokes, C., Wheate, R., Winsvold, S., Wolken, G., Wyatt, F., and Zheltyhina, N.: Randolph Glacier Inventory [v2.0]: A Dataset of Global Glacier Outlines, Global Land Ice Measurements from Space, Boulder Colorado, USA, Digital Media, edited by: Bajracharya, S. R. and Shresta, B., The Status of Glaciers in the Hindu Kush-Himalayan Region, Kathmandu: ICIMOD, 2011, 2012.

Arendt, A., Bliss, A., Bolch, T., Cogley, J. G., Gardner, A. S., Hagen, J.-O., Hock, R., Huss, M., Kaser, G., Kienholz, C., Pfeffer, W. T., Moholdt, G., Paul, F., Radić, V., Andreassen, L., Bajracharya, S., Barrand, N. E., Beedle, M., Berthier, E., Bhambri, R., Brown, I., Burgess, E., Burgess, D., Cawkwell, F., Chinn, T., Copland, L., Davies, B., De Angelis, H., Dolgova, E., Earl, L., Filbert, K., Forester, R., Fountain, A. G., Frey, H., Giffen, B., Glasser, N., Guo, W. Q., Gurney, S., Hagg, W., Hall, D., Haritashya, U. K., Hartmann, G., Helm, C., Herreid, S., Howat, I., Kapustin, G., Khromova, T., König, M., Kohler, J., Kriegel, D., Kutuzov, S., Lavrentiev, I., LeBris, R., Liu, S. Y., Lund, J., Manley, W., Marti, R., Mayer, C., Miles, E. S., Li, X., Menounos, B., Mercer, A., Mölg, N., Mool, P., Nosenko, G. Negrete, A., Nuimura, T., Nuth, C., Pettersson, R., Racoviteanu, A., Ranzi, R., Rastner, P., Rau, F., Raup, B., Rich, J., Rott, H., Sakai, A., Schneider, C., Seliverstov, Y., Sharp, M., Sigurðsson, O., Stokes, C., Way, R. G., Wheate, R., Winsvold, S., Wolken, G., Wyatt, F., and Zheltyhina, N.: Randolph Glacier Inventory - A Dataset of Global Glacier Outlines: Version 5.0. Global Land Ice Measurements from Space, Boulder Colorado, USA, Digital Media, 2015.

Bajracharya, S. R. and Shresta, B. (Eds.): The Status of Glaciers in the Hindu Kush-Himalayan Region, Kathmandu: ICIMOD, 2011.

Bajracharya, S. R., Maharjan, S. B., and Shrestha, F.: The status and decadal change of glaciers in Bhutan from the 1980s to 2010 based on satellite data, Ann. Glaciol., 55, 66, doi:10.3189/2014AoG66A125, 2014.

Barr, I. D. and Clark, C. D.: Glaciers and climate in Pacific Far NE Russia during the Last Glacial Maximum, J. Quaternary Sci., 26, 227-237, 2011.

Barr, I. D. and Clark, C. D.: An updated moraine map of Far NE Russia, Journal of Maps, 8, 431-436, 2012a.

Barr, I. D. and Clark, C. D.: Late Quaternary glaciations in Far NE Russia; combining moraines, topography and chronology to assess regional and global glaciation synchrony, Quaternary Sci. Rev., 53, 72-87, 2012b.

Barr, I. D. and Solomina, O.: Pleistocene and Holocene glacier fluctuations upon the Kamchatka Peninsula, Global Planet. Change, 113, 110-120, 2014

Bhambri, R., Bolch, T., and Chaujar, R. K.: Mapping of debriscovered glaciers in the Garhwal Himalayas using ASTER DEMs and thermal data, Int. J. Remote Sens., 32, 8095-8119, 2011.

Bhambri, R., Bolch, T., Kawishwar, P., Dobhal, D. P., Srivastava, D., and Pratap, B.: Heterogeneity in glacier response in the upper Shyok valley, northeast Karakoram, The Cryosphere, 7, 13851398, doi:10.5194/tc-7-1385-2013, 2013.
Bolch, T., Yao, T., Kang, S., Buchroithner, M. F., Scherer, D., Maussion, F., Huintjes, E., and Schneider, C.: A glacier inventory for the western Nyainqentanglha Range and the Nam Co Basin, Tibet, and glacier changes 1976-2009, The Cryosphere, 4, 419433, doi:10.5194/tc-4-419-2010, 2010.

Braitseva, O. A., Melekestsev, I. V., Ponomareva, V. V., and Sulerzhitsky, L. D.: Ages of calderas, large explosive craters and active volcanoes in the KuriI-Kamchatka region, Russia Bulletin of Volcanology, 57, 383-402, 1995.

Braitseva, O. A., Ponomareva, V. V., Sulerzhitsky, L. D., Melekestsev, I. V., and Bailey, J.: Holocene Key-Marker Tephra Layers in Kamchatka, Russia, Quaternary Res., 47, 125-139, 1997.

Bulin, N. K.: Abyssal structure of Kamchatka and the Kuril Islands from seismic data, Int. Geol. Rev., 20, 777-784, 1978.

Burns, P. and Nolin, A.: Using atmospherically-corrected Landsat imagery to measure glacier area change in the Cordillera Blanca, Peru from 1987 to 2010, Remote Sens. Environ., 140, 165-178, 2014.

Copland, L., Sharp, M. J., and Dowdeswell, J. A.: The distribution and flow characteristics of surge-type glaciers in the Canadian High Arctic, Ann. Glaciol., 36, 73-81, 2003.

DeBeer, C. M. and Sharp, M. J.: Recent changes in glacier area and volume within the southern Canadian Cordillera, Ann. Glaciol., 46, 215-221, 2007.

Earl, L. and Gardner, A.: A satellite-derived glacier inventory for North Asia, Ann. Glaciol., 57, 50-60, doi:10.3189/2016AoG71A008, 2016.

Evans, I. S.: Local aspect asymmetry of mountain glaciation: A global survey of consistency of favoured directions for glacier numbers and altitudes, Geomorphology, 73, 166-184, 2006.

Farinotti, D., Longuevergne, L., Moholdt, G., Duethmann, D., Mölg, T., Bolch, T., Vorogushyn, S., and Güntner, A.: Substantial glacier mass loss in the Tien Shan over the past 50 years, Nature Geosci., 8, 716-723, 2015.

Farr, T. G., Rosen, P. A., Caro, E., Crippen, R., Duren, R., Hensley, S., Kobrick, M., Paller, M., Rodriguez, E., Roth, L., Seal, D., Shaffer, S., Shimada, J., Umland, J., Werner, M., Orkin, M., Burbank, D., and Alsdor, D.: The Shuttle Radar Topography Mission, Rev. Geophys., 45, RG2004, doi:10.1029/2005RG000183, 2007.

Fischer, M., Huss, M., and Hoelzle, M.: Surface elevation and mass changes of all Swiss glaciers 1980-2010, The Cryosphere, 9, 525-540, doi:10.5194/tc-9-525-2015, 2015.

Frey, H., Paul, F., and Strozzi, T.: Compilation of a glacier inventory for the western Himalayas from satellite data: methods, challenges, and results, Remote Sens. Environ., 124 832-843, 2012.

$\mathrm{Fu}$, P. and Rich, P. M.: A geometric solar radiation model with applications in agriculture and forestry, Computers and Electronics in Agriculture, 37, 25-35, 2002.

Gao, J. and Lui, Y.: Applications of remote sensing, GIS and GPS in glaciology: a review, Prog. Phys. Geogr., 25, 520-540, 2001.

Granshaw, F. D. and Fountain, A. G.: Glacier change (1958-1998) in the North Cascades National Park Complex, Washington, USA, J. Glaciol., 52, 251-256, 2006.

Huss, M.: Extrapolating glacier mass balance to the mountain-range scale: the European Alps 1900-2100, The Cryosphere, 6, 713727, doi:10.5194/tc-6-713-2012, 2012. 
Ivanov, A.: Kamchatka, in: The Physical Geography of Northern Eurasia, edited by: Shahgedanova, M., Oxford University Press, 403-421, 2002.

Kääb, A.: Remote sensing of mountain glaciers and permafrost creep, Zürich, Universität Zürich, Geographisches Institut (Schriftenreihe Physische Geographie 48) 2005.

Kalnay, E., Kanamitsu, M., Kistler, R., Collins, W., Deaven, D., Gandin, L., Iredell, M., Saha, A., White, G., Woollen, J., Zhu, Y., Chelliah, M., Ebisuzaki, W., Higgins, W., Janowiak, J., Mo, K. C., Ropelewski, C., Wang, J., Leetmaa, A., Reynolds, R., Jenne, R., and Joseph, D.: The NCEP/NCAR 40-year Reanalysis Project, B. Am. Meteorol. Soc., 77, 437-471, 1996.

Kamp, U. and Pan, C. G.: Inventory of glaciers in Mongolia, derived from Landsat imagery from 1989 to 2011, Geografiska Annaler: Series A, Physical Geography, 94, 653-669, doi:10.1111/geoa.12105, 2015.

Khromova, T., Nosenko, G., Kutuzov, S., Muraviev, A., and Chernova, L.: Glacier area changes in Northern Eurasia, Environ. Res. Lett., 9, 015003, doi:10.1088/1748-9326/9/1/015003, 2014.

Kotlyakov, V. M.: Problems and results of studies of mountain glaciers in the Soviet Union, World Glacier Inventory - Proceedings of the Riederalp Workshop, September 1978 IAHS-AISH, 126, 129-137, 1980.

Lemke, P., Ren, J., Alley, R. B., Allison, I., Carrasco, J., Flato, G., Fujii, Y., Kaser, G., Mote, P., Thomas, R. H., and Zhang, T.: Observations: Changes in Snow, Ice and Frozen Ground, in: Climate Change 2007: The Physical Science Basis, Contribution of Working Group I to the Fourth Assessment Report of the Intergovernmental Panel on Climate Change, edited by: Solomon, S., Qin, D., Manning, M., Chen, Z., Marquis, M., Averyt, K. B., Tignor, M., and Miller, H. L., Cambridge University Press, Cambridge, United Kingdom and New York, NY, USA, 337-383, 2007.

Malinverni, E. S., Croci, C., and Sgroi, F.: Glacier Monitoring by Remote sensing and GIS techniques in Open Source Environment, EARSeL eProceedings, 7, 120-132, 2008.

Man, Q. M., Guo, H. D., Liu, G., and Dong, P. L.: Comparison of different methods for monitoring glacier changes observed by Landsat images, IOP Conference Series: Earth and Environmental Science, 17, 012127, doi:10.1088/1755-1315/17/1/012127, 2014.

Manevich, T. M. and Samoilenko, S. B.: Glaciers of the Koryak Volcano, Ice and Snow, 52, 25-30, 2012.

Manevich, T. M., Muraviev, Y. D., and Samoilenko, S. B.: Glaciers of the Avachinskaya volcano group: current condition (state), Ice and Snow, 55, 14-26, 2015.

Matoba, S., Ushakov, S. V., Shimbori, K., Sasaki, H., Yamasaki, T., Ovshannikov, A. A., Manevich, A. G., Zhideleeva, T. M., Kutuzov, S., Muravyev, Y. D., and Shiraiwa, T.: The glaciological expedition to Mount Ichinsky, Kamchatka, Russia, Bull. Glaciol. Res., 24, 79-85, 2007.

Muraviev, Y. D.: Present day glaciation in Kamchatka-distribution of glaciers and snow, Cryospheric Studies in Kamchatka II (Institute of Low Temperature Science, Hokkaido University, 1-7, 1999.

Muraviev, A. Y.: Glacier size changes in Kronotsky Peninsula and Alney-Chashakondzha Massif, Kamchatka Peninsula in the second half of XX century and the beginning of XXI century, Ice and Snow, 2, 22-28, 2014 (summary in English).
Muraviev, A. Y. and Nosenko, G. A.: Glaciation change in northern part of the Middle Range on Kamchatka Peninsula in the second half of the XX century Ice and Snow, 2, 5-12, 2013 (in Russian with English abstract).

Muraviev, Y. D., Tsvetkov, D. G., Muraviev, A. Y., and Osipova, G. B.: Dynamics of the Bilchenok Surging Glacier in the Klyuchevskaya, Ice and Snow, 52, 31-39, 2012.

Narozhniy, Y. and Zemtsov, V.: Current state of the Altai glaciers (Russia) and trends over the period of instrumental observations 1952-2008, Ambio, 40, 575-588, 2011.

Nuimura, T., Sakai, A., Taniguchi, K., Nagai, H., Lamsal, D., Tsutaki, S., Kozawa, A., Hoshina, Y., Takenaka, S., Omiya, S., Tsunematsu, K., Tshering, P., and Fujita, K.: The GAMDAM glacier inventory: a quality-controlled inventory of Asian glaciers, The Cryosphere, 9, 849-864, doi:10.5194/tc-9-8492015, 2015.

Oerlemans, J., Anderson, B., Hubbard, A., Huybrechts, P., Johannesson, T., Knap, W. H., Schmeits, M., Stroeven, A. P., van der Wal, R. S. W., Wallinga, J., and Zuo, Z.: Modelling the response of glaciers to climate warming, Clim. Dynam., 14, 267-274, 1998.

Paul, F. and Andreassen, L. M.: A new glacier inventory for the Svartisen region, Norway, from Landsat ETM+ data: challenges and change assessment, J. Glaciol., 55, 607-618, 2009.

Paul, F. and Haeberli, W.: Spatial variability of glacier elevation changes in the Swiss Alps obtained from two digital elevation models, Geophys. Res. Lett., 35, L21502, doi:10.1029/2008GL034718, 2008.

Paul, F., Kääb, A., and Haeberli, W.: Recent glacier changes in the Alps observed by satellite: Consequences for future monitoring strategies, Global Planet. Change, 56, 111-122, 2007.

Paul, F., Barry, R., Cogley, G., Frey, H., Haeberli, W., Ohmura, A., Ommanney, S., Raup, B., Rivera, A., and Zemp, M.: Recommendations for the compilation of glacier inventory data from digital sources, Ann. Glaciol., 51, 1-8, 2009.

Paul, F., Barrand, N. E., Baumann, S., Berthier, E., Bolch, T., Casey, K., Frey, H., Joshi, S. P., Konovalov, V., Le Bris, R., Mölg, N., Nosenko, G., Nuth, C., Pope, A., Racoviteanu, A., Rastner, P., Raup, B., Scharrer, K., Steffen, S., and Winsvold, S.: On the accuracy of glacier outlines derived from remote-sensing data, Ann. Glaciol., 54, 171-182, 2013.

Pfeffer, W. T., Arendt, A., Bliss, A., Bolch, T., Cogley, J., Gardner, A., Hagen, J., Hock, R., Kaser, G., Kienholz, C., Miles, E., Moholdt, G., Mölg, N., Paul, F., Radic, V., Rastner, P., Raup, B., Rich, J., Sharp, M., and Consortium, T. R.: The Randolph Glacier Inventory: a globally complete inventory of glaciers, J. Glaciol., 60 537-552, 2014.

Pieczonka, T. and Bolch, T.: Region-wide glacier mass budgets and area changes for the Central Tien Shan between $~ 1975$ and 1999 using Hexagon KH-9 imagery, Global Planet. Change, 128, 113,2015

Ponomareva, V., Melekestsev, I., Braitseva, O., Churikova, T., Pevzner, M., and Sulerzhitsky, L.: Late Pleistocene-Holocene Volcanism on the Kamchatka Peninsula, Northwest Pacific Region Volcanism and Subduction: The Kamchatka Region Geophysical Monograph Series, 172, 165-198, 2007.

Ponomareva, V., Portnyagin, M., Derkachev, A., Pendea, I. F., Bourgeois, J., Reimer P. J., Garbe-Schönberg, D., Krasheninnikov, S., and Nürnberg, D.: Early Holocene $M \sim 6$ explosive eruption 
from Plosky volcanic massif (Kamchatka) and its tephra as a link between terrestrial and marine paleoenvironmental records, International J. Earth Sci. (Geol. Rundsch.), 102, 1673-1699, doi:10.1007/s00531-013-0898-0, 2013.

Racoviteanu, A., Arnaud, Y., and Williams, M.: Decadal changes in glacier parameters in Cordillera Blanca, Peru derived from remote sensing, J. Glaciol., 54, 499-510, 2008.

Racoviteanu, A. E., Arnaud, Y., Williams, M. W., and Manley, W. F.: Spatial patterns in glacier characteristics and area changes from 1962 to 2006 in the Kanchenjunga-Sikkim area, eastern Himalaya, The Cryosphere, 9, 505-523, doi:10.5194/tc-9-5052015, 2015.

Ramírez, E., Francou, B., Ribstein, P., Descloitres, M., Guerin, R., Mendoza, J., Gallaire, R., Pouyaud, B., and Jordan, E.: Small glaciers disappearing in the tropical Andes: a case-study in Bolivia: Glaciar Chacaltaya (16 S), J. Glaciol., 47, 187-194, 2001.

Raup, B., Kääb, A., Kargel, J. S., Bishop, M. P., Hamilton, G., Lee, E., Paul, F., Rau, F., Soltesz, D., Khalsaa, S. J. S., Beedle, M., and Helm, C.: Remote sensing and GIS technology in the Global Land Ice Measurements from Space (GLIMS) Project, Computers and Geosciences, 33, 104-125, 2007.

Shiraiwa, T., Muravyev, Y. D., Kameda, T., Nishio, F., Toyama, Y., Takahashi, A., Ovsyannikov, A. A., Salamatin, A. N., and Yamagata, K.: Characteristics of a crater glacier at Ushkovsky volcano, Kamchatka, Russia, as revealed by the physical properties of ice cores and borehole thermometry, J. Glaciol., 47, 423-432, 2001.

Smith, T., Bookhagen, B., and Cannon, F.: Improving semiautomated glacier mapping with a multi-method approach: applications in central Asia, The Cryosphere, 9, 1747-1759, doi:10.5194/tc-9-1747-2015, 2015.

Solomina, O., Wiles, G., Shiraiwa, T., and D'Arrigo, R.: Multiproxy records of climate variability for Kamchatka for the past 400 years, Clim. Past, 3, 119-128, doi:10.5194/cp-3-119-2007, 2007.

Stokes, C. R., Shahgedanova, M., Evans, I., and Popovnin, V. V.: Accelerated loss of alpine glaciers in the Kodar Mountains, south-eastern Siberia, Global Planet. Change, 101, 82-96, 2013.

Tennant, C., Menounos, B., Wheate, R., and Clague, J. J.: Area change of glaciers in the Canadian Rocky Mountains, 1919 to 2006, The Cryosphere, 6, 1541-1552, doi:10.5194/tc-6-15412012, 2012.
Tielidze, L. G.: Glacier change over the last century, Caucasus Mountains, Georgia, observed from old topographical maps, Landsat and ASTER satellite imagery, The Cryosphere, 10, 713725, doi:10.5194/tc-10-713-2016, 2016.

Velichko, A. and Spasskaya, I.: Climate Change and the Development of Landscapes, in: The Physical Geography of Northern Eurasia, edited by: Shahgedanova, M, Oxford University Press, 36-69, 2002.

Vinogradov, V. N.: Katalog lednikov SSSR, Kamchatka [Inventory of glaciers of the USSR, Kamchatka], v. 20: Leningrad, Gidrometeoizdat, 2-4, 1968 (in Russian).

Vinogradov, V. N., Muravyev, Y. D., and Ovsyannikov, A. A.: Influence of eruption of Plosky Tolbachik volcano in 1975-76 on snow cover and glaciers, Voprosy Geographii Kamchatki, 9, 95102, 1985 (in Russian).

VONA/KVERT Weekly Release, 26 May 2016, KVERT, Institute of Volcanology and Seismology FEB RAS, available at: http:// www.kscnet.ru/ivs/kvert/van/index.php?n=21-2016, last access: 27 May 2016.

WGMS: World Glacier Inventory - Status 1988, edited by: Haeberli, W., Bösch, H., Scherler, K., Østrem, G., and Wallén, C. C., IAHS (ICSI)/UNEP/UNESCO, World Glacier Monitoring Service, Zurich, Switzerland, 458, 1989.

Yamaguchi, S., Shiraiwa, T., Nishimura, K., Matsumoto, T., Kohshima, S., Muravyev, Y., and Naruse, R.: Distribution and short-term variations of flow velocities at Koryto Glacier in the Kronotsky Peninsula, Kamchatka, Russia, in 1997, Bull. Glaciol. Res., 16, 51-56, 1998.

Yamaguchi, S., Sawagaki, T., Matsumoto, T., Muravyev, Y. D., and Naruse, R.: Influence of Debris Cover on Ogive-like Surface Morphology of Bilchenok Glacier inKamchatka, Arctic, Antarctic, and Alpine Research, 39, 332-339, 2007.

Yamaguchi, S., Naruse, R., and Shiraiwa, T.: Climate reconstruction since the Little Ice Age by modelling Koryto glacier, Kamchatka Peninsula, Russia, J. Glaciol., 54, 125-130, 2008. 